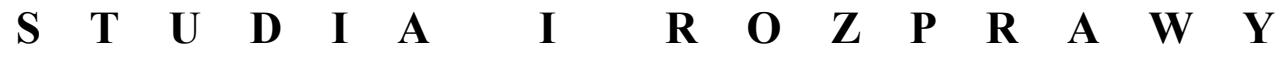

ROCZNIKI HUMANISTYCZNE

Tom LXVIII, zeszyt 7 - 2020

DOI: http://dx.doi.org/10.18290/rh20687-1

IWONA RZEPNIKOWSKA

\section{PIĘKNA (NIE)OBECNA, CZYLI MELUZYNA W POLSKIM FOLKLORZE BAJKOWYM}

Meluzyna to bohaterka tradycyjnych legend popularnych we Francji co najmniej od wieku XII, przedstawiana w nich jako kobieta wyposażona od pasa w dół w smoczo-wężowe atrybuty (Krzyżanowski, Polska bajka ludowa 67-71). Zdaniem jednak wielu badaczy przekazy o Meluzynie mają znacznie starsze źródła, których jedni doszukują się w mitologii europejskiej - głównie greckiej i celtyckiej - inni zaś w orientalnej. Dokładne wskazanie genezy opowieści nie wydaje się możliwe, ponieważ wyzyskany w nich schemat fabularny stanowił dobro wspólne niemal wszystkich kręgów kulturowych ${ }^{1}$.

Meluzyna to także tytułowa bohaterka późnośredniowiecznego francuskiego romansu rycerskiego, znanego w dwóch wersjach literackich - proza-

Dr hab. IwONA RZEPNIKOwSKA, prof. UMK - Uniwersytet Mikołaja Kopernika w Toruniu, Wydział Humanistyczny, Instytut Literaturoznawstwa, Katedra Literatur Słowiańskich; adres do korespondencji: ul. Fosa Staromiejska 3, pok. 313A, 87-100 Toruń; e-mail: iwo@umk.pl. ORCID: https://orcid.org/0000-0001-5709-1714.

Dr habil. IwONA RZEPNIKOwSKA, prof. at UMK - Nicolaus Copernicus University in Toruń, Faculty of Humanities, Institute of Literature, Department of Slavonic Literatures; address for correspondene: ul. Fosa Staromiejska 3, pok.313A, 87-100 Toruń; e-mail: iwo@umk.pl. ORCID: https://orcid.org/0000-0001-5709-1714.

${ }^{1}$ Chodzi o związek mężczyzny z istotą czasowo przybierającą postać ludzko-zwierzęcej hybrydy, uwarunkowany koniecznością dotrzymania przez oblubieńca określonej obietnicy. Bohater łamie jednak tabu, w czego wyniku traci na zawsze ukochaną żonę i szczęście. Najbardziej znaną realizacją powyższej matrycy narracyjnej jest wątek T 400 „Mąż szuka utraconej żony” (Krzyżanowski, Polska bajka ludowa 126-129). Z najnowszej systematyki międzynarodowych wątków bajkowych, sporządzonej przez Hansa-Jörga Uthera, wynika, że typ fabularny ATU 400 „The Man on a Quest for His Lost Wife" jest znany niemal na całym świecie (Uther 231-234). Warto odnotować, że historia o Meluzynie doczekała się wielu opracowań naukowych (Por. np. Kohler; Heisig 170-181; Le Goff i Le Roy Ladurie 587-622; Lecouteux, „La Structure” 294-306; Lecouteux, „Zur Entstehung” 73-84; Ruh; Walter; Zhao; Melusine's Footprint). 
torskiej oraz wierszowanej. Autorem pierwszej z nich jest Jean d'Arras, dworzanin Jana Wspaniałego, księcia Berry i Owerni, hrabiego Poitiers (1387), natomiast drugiej - bliżej nieznany duchowny Coudrette (Couldrette) z Poitiers, który opracował dzieje zagadkowej bohaterki na zlecenie Guillaume'a VII de Parthenay-l'Archevêque (Le roman de Melusine, ou de Parthenay, ou de Lusignan, 1401). Przy wszelkich dzielących je różnicach obydwa utwory stanowiły rodzaj legendy herbowej, nobilitującej ród Lusignanów, których protoplaści mieli być zrodzeni ze związku mężczyzny z istotą reprezentującą wyższy, nadludzki porządek, na co wskazuje podwójna zooantropomorficzna natura Meluzyny. Opowieści tego typu wiąże się z szeroko rozpowszechnionymi w kulturze mitami totemicznymi, przy czym przekazy o żonie jako postaci totemicznej uznaje się za wcześniejsze w stosunku do fabuł wprowadzających w to miejsce niezwykłego małżonka (Mieletinski 325) ${ }^{2}$. Niewątpliwie tak odległa, mityczna genealogia rodu wzmacniała poczucie wyjątkowości jego przedstawicieli, legitymizując jednocześnie wzrastającą potęgę terytorialną, polityczną i kulturowo-cywilizacyjną Lusignanów. Ponadto romans o Meluzynie doskonale wpisywał się w średniowieczną tradycję, gdyż dość powszechnie doszukiwano się powiązań znanych postaci historycznych z istotami nadludzkimi. Dość wspomnieć Ryszarda Lwie Serce czy Aleksandra Wielkiego.

\section{TREŚĆ ROMANSU O MELUZYNIE}

W wersji prozatorskiej treść Historii o Meluzynie przedstawia się następująco:

W czasie polowania Rajmund z Poitiers przypadkowo zabija swego stryja, hrabiego Emeryka. Zrozpaczony młodzieniec zapuszcza się w leśne ostępy i w pobliżu źródła skalnego zwanego Zdrojem Pragnących spotyka piękną pannę imieniem Meluzyna. Proponuje mu ona pomoc w zatajeniu przyczyny śmierci krewnego pod warunkiem jednak, że ją poślubi i nie będzie widywał w soboty. Dotrzymanie umowy zapewni mu szczęście i bogactwo, jej zaś złamanie będzie miało dla niego tragiczne skutki. Rajmund przyjmuje postawione warunki, a następnie od spadkobierców stryja otrzymuje taki obszar ziemi, jaki za radą małżonki udało mu się objąć skórą jelenia pociętą na

\footnotetext{
${ }^{2}$ Dlatego mitologicznych źródeł fabuły romansu należałoby szukać wśród realizacji wątku ATU 400, nie zaś, jak podają niektórzy badacze, wśród historii typu ATU 425 „The Search for the Lost Husband" (Uther I, 247-248).
} 
pasy. Meluzyna wznosi na niej okazały zamek, wokół którego z czasem powstaje osada, dająca początek miastu Lozannie.

W ciągu trwającego wiele lat małżeństwa Meluzyna rodzi Rajmundowi dziesięciu synów. Każdy z nich - z wyjątkiem dwu najmłodszych - odbiega w budowie anatomicznej od ogólnie przyjętej normy. Kiedy synowie dorastają, matka wyprawia ich w świat w poszukiwaniu przygód i zaszczytów. Jako pierwsi wyruszają Urion i Guion, za nimi - Antoine i Regnault. Cała czwórka niezwykle szybko robi świetną karierę, żeniąc się z księżniczkami, które obronili przed wrogiem czyhającym na ich życie i majątek. Każdy z synów Meluzyny staje się w ten sposób protoplastą nowej gałęzi rodu Lusignanów (Urion został królem Cypru, Guion - Armenii, Regnault Luksemburga, Antoine - Czech), wywodzącej się tym razem od męskiego przodka naznaczonego zaświatowymi koneksjami, co dla członków arystokratycznej wspólnoty miało charakter nobilitujący ${ }^{3}$.

Znaczna część utworu poświęcona jest opowieściom o dokonaniach najstraszliwszego z potomków założycielki klanu, Geoffroya au Grand Dent. Dopuścił się on m.in. spalenia klasztoru wraz z przebywającymi w nim mnichami, wśród których był także jego brat, Froymond, uważając, że stan zakonny uwłacza rycerskim tradycjom Lusignanów. Rajmund, poruszony zbrodnią popełnioną przez syna i zaskoczony niezrozumiałą reakcją Meluzyny, zdającej się pochwalać czyn ich potomka, winą za jego okrucieństwo obarczył małżonkę, czyniąc niedwuznaczną aluzję do jej nieludzkiej natury. Tym samym przyznał, że nie dotrzymał obietnicy złożonej niegdyś ukochanej i podpatrzył ją podczas kąpieli w Zdroju Pragnących, choć uczynił to za namową brata. Zrozpaczona Meluzyna przybiera swą pierwotną antropozoomorficzną postać i w tym wcieleniu ulatuje z zamku przez okno, oznaj-

\footnotetext{
${ }^{3}$ Jak już wspomniano, ośmiu z dziesięciu synów Meluzyny wykazuje jakieś odstępstwo od normy w zakresie fizyczności: „(...) porodziła pierworodnego syna, a tego Urionem okrzcić dała. Ten lubo był wzro〈st>u kształtnego, członków mocnych, jednak dziwnej twarzy był, abowiem miał lice jakoby zgniecione, do tego był krótkiej twarzy, oko jedno miał czerwone, a drugie zielone, ust był barzo szerokich, a uszu długich” (Historia o szlachetnej 76). „(...) nazwała imię jego Gijon. Ten oko jedno wyżej miał niźli drugie - we wszytkim innym był udatny” (79). ,,...) porodziła czwartego syna na imię Antoni. Ten miał na twarzy lwią łapę, a był ciała kosmatego i paznoktów lwich, skąd był wejźrzenia tak srogiego, iż kto nań weźrzał, wezdrgnąć się musiał, bo się przy srogości onej nie taiła moc wielka w nim” (79-80). „(...) ten między nosem a czołem prawie we śrzodku tylko jedno oko miał, we wszytkim innym udatny był (co potym broił usłyszemy niżej). Tego przezwała matka Reinhardem" (80). Cielesna odmienność potomków Meluzyny stanowi przejaw szeroko pojmowanej obcości. W perspektywie antropologicznokulturowej jednostkom przynależnym do tej kategorii przypisywano, z jednej strony, etiologię negatywną (odraza, przerażenie), z drugiej zaś postrzegano jako istoty o nadprzyrodzonym potencjale, a więc pozostające w jakiś sposób w kontakcie z sacrum (Benedyktowicz 149).
} 
miwszy przedtem, że postępek Geoffroya uchronił ich ród przed zagładą, a kolejne zagrożenie stanowi syn Horybal. Ponadto zapowiedziała, iż będzie nawiedzać zamek, ,jak tylko w nim pan nowy nastanie” (Historia o szlachetnej 138).

Tajemnica pochodzenia Meluzyny, skrzętnie ukrywana nawet przed bliskimi, wyjaśnia się dopiero podczas wyprawy Geoffroya do Norwegiej ${ }^{4}$. Okazuje się, że jego matka była najmłodszą córką czarodziejki Presiny i króla Helmesa z Albanii. Presina rzuciła na Meluzynę i jej siostry, Meliorę i Palatinę, klątwę po tym, jak zamknęły one w jaskini ojca, gdyż nie dotrzymał on przyrzeczenia danego niegdyś żonie i odwiedził ją w połogu. Meluzyna jako inicjatorka zemsty na rodzicu miała w każdą sobotę przybierać postać kobiety-węża, a gdyby ktoś dowiedział się o tej jej przypadłości, wtedy pozostałaby takim monstrum „aż do dnia sądnego” (135). Natomiast przeklęte przez matkę Palatina i Meliora strzegły skarbów w Armenii i Aragonii, czekając na śmiałków, którzy odważą się zdobyć pilnie nadzorowane kosztowności. Jednym z nich będzie rycerz króla Artura, a drugim Gis, wnuk Meluzyny. Romans kończy się dość niespodziewanie śmiercią Geoffreya, zamierzającego odzyskać resztę skarbów rodowych i zorganizować wyprawę do Grobu Pańskiego ${ }^{5}$.

W wierszowanej wersji romansu przebieg zdarzeń jest w zasadzie podobny, ale znacznie ograniczono w nim udział elementów fantastycznych na rzecz dążenia do ukazania czynów potomków założycieli rodu w zgodzie z chrześcijańskim wzorem rycerza (11-12).

\section{HISTORIA O MELUZYNIE W OBIEGU JARMARCZNYM}

Recepcja romansu początkowo była ograniczona jedynie do elit dworskich, dość szybko jednak zaczęła obejmować coraz szersze kręgi odbiorców, w czym niebagatelną rolę odegrały thumaczenia $i$ adaptacje utworu na języki obce, a także wynalezienie druku. Początki europejskiej kariery romansu przypadają na rok 1456, czyli rok publikacji jego przekładu na język niemiecki, którego podstawę stanowiła wierszowana, nie zaś - jak sądzono do niedawna - prozatorska wersja historii (Krzywy 12). W następnym stuleciu z niemieckiego utwór przetłumaczono na język czeski i polski (Historya wdzięczna o szlachetnej a pięknej Meluzynie teraz nowo z niemieckiego języka

\footnotetext{
${ }^{4}$ Norwegiej (T: Norheme, Norwegen, C: Nochaubellande) - mowa o hrabstwie Northumberland w północno-wschodniej Anglii, przy granicy ze Szkocją (Historia o szlachetnej 133).

${ }^{5}$ Streszczenie romansu o Meluzynie sporządzono na podstawie jego wersji opracowanej przez Romana Krzywego (Historia o szlachetnej 49-180).
} 
na polski przełożona przez Marcina Siennika, Kraków 1569), z polskiego zaś dokonano dwóch przekładów na język rosyjski, ale nastąpiło to dopiero w drugiej połowie XVII wieku' ${ }^{6}$. Wielu tłumaczeń (m.in. na łaciński, hiszpański, portugalski) doczekał się także romans o Meluzynie prozą, a niewątpliwie stało się tak za sprawą jego publikacji w formie drukowanej w $1478 \mathrm{r}$.

Dzięki przekładom na inne języki, a także ich wielokrotnym wznowieniom w poszczególnych krajach obydwa utwory weszły wkrótce do europejskiego kanonu literatury jarmarcznej, zwłaszcza że autorzy tłumaczeń i parafraz swobodnie posługiwali się elementami fikcji i prawdy, wykorzystywali ogólnie znane motywy wędrowne, a także stereotypy konstrukcyjne charakterystyczne dla różnorodnych konwencji gatunkowych. Jeśli do tego dodamy jeszcze frapującą postać bohaterki oraz rycerskie przygody jej synów, a także uwzględnimy fakt, że wznowienia przekładów były tłoczone na papierze niskiego gatunku, często ozdobione rycinami, to w tej postaci Historia o Meluzynie rzeczywiście znakomicie nadawała się do tego, by zaspokoić potrzeby literackie mało wymagającego czytelnika, spragnionego lektury przede wszystkim sensacyjno-przygodowej (Lugowska, „Meluzyna” 375-376).

\section{MELUZYNA W PLANIE MITOLOGICZNYM}

Na plan pierwszy w kulturowej charakterystyce Meluzyny wysuwa się żywioł wody. Wskazuje na to rzeka (w najstarszej wersji legendy, przekazanej przez Gerwazego z Tilbury w dziele Otia imperialia, ok. 1218 r.) bądź źródło (literackie opracowania legendy) (Małek 12-13), w których pobliżu dochodzi do spotkania Rajmunda i tajemniczej istoty, zwłaszcza jednak zażywane przez nią cotygodniowe kąpiele, przypominające rytualne ablucje, oparte na wierze w oczyszczającą i regenerującą ciało i duszę moc wody (Eliade 194-195; Moszyński 509).

Woda jako istotny element kształtujący symboliczno-wyobrażeniową tożsamość bohaterki niniejszej analizy nie wydaje się przypadkowa, gdyż w najstarszych kręgach kulturowych była ona pojmowana jako odwieczna materia, prapoczątek wszelkiego istnienia, życiodajny składnik Kosmosu ${ }^{7}$. Zawarte $\mathrm{w}$ wodzie moce witalne $\mathrm{w}$ połączeniu $\mathrm{z}$ pierwiastkiem kobiecym

\footnotetext{
${ }^{6}$ Recepcji romansu o Meluzynie w Rosji poświęciła swoje studium Eliza Małek. Badaczka podkreśla, że zachowało się jedynie drugie wydanie przekładu romansu o Meluzynie z $1671 \mathrm{r}$., które stało się podstawą do tłumaczenia na język rosyjski (Małek 23-24).

${ }^{7} \mathrm{Na}$ temat ogólnokulturowych przekonań, że woda podtrzymuje życie i jest jego źródłem zob. (Виноградова 386-390; Majer-Baranowska 153-187; Eliade 188-211).
} 
tłumaczyłyby fakt tak licznego potomstwa wydanego na świat przez Meluzynę, a także zdobyte dzięki niej przez małżonka zaszczyty i bogactwo. Meluzyna jednak jest postacią hybrydyczną, łączącą w sobie cechy istot reprezentujących różne porządki. Jej wężowo-smocze atrybuty wskazują z jednej strony na przynależność do świata podziemnego, wiązanego zarówno ze śmiercią, jak i z wegetacją, z drugiej zaś sytuują ją bliżej żywiołu powietrza, co by tłumaczyło sposób, w jaki Meluzyna opuszcza zamek małżonka.

Brak natomiast jakichkolwiek odwołań do ognistej natury smoka ${ }^{8}$, dlatego - wbrew opiniom niektórych badaczy (Krzywy 24) - trudno postrzegać Meluzynę jako upostaciowanie wszystkich czterech żywiołów. Można by nawet zaryzykować stwierdzenie, że obecne w mityczno-kulturowej identyfikacji założycielki rodu Lusignanów woda, ziemia i powietrze tworzą rodzaj wspólnoty przeciwstawionej pierwiastkowi ognia. Jedynie w pierwotnej wersji legendy, w której tabuizacji podlegała nagość bohaterki, będąca, jak wiadomo, ważnym elementem charakterystyki sacrum, Meluzyna mogła uosabiać ideę nieskończoności, jedności i pełni.

\section{MELUZYNA A POLSKI FOLKLOR BAJKOWY}

Wydawałoby się, że opowieść o Meluzynie, głównie dzięki popularności i atrakcyjności motywów, z jakich zbudowana jest jej pierwsza część (małżeństwo $\mathrm{z}$ istotą totemiczną, złamanie przez człowieka przyrzeczenia danego niezwykłemu małżonkowi), a także wyzyskaniu wielu innych elementów baśniowo-fantastycznych spełniała wszelkie warunki, by zasilić twórczość oralną. Tymczasem w polskim folklorze bajkowym trudno odnaleźć bezpośrednie dowody recepcji Historii o Meluzynie. Można natomiast mówić o pośrednich świadectwach jej funkcjonowania w obiegu ustnym, przy czym na ograniczonym terytorialnie obszarze (Wróblewska 158-159). Wskazuje na to zbiór legend i baśni śląskich, opracowanych literacko przez Stanisława Wasylewskiego, zawierający m.in. opowieść pod dość znamiennym tytułem Meluzyna, czyli panna z ślaskiego wiatru (Wasylewski 13-18) ${ }^{9}$. Dokładnych

\footnotetext{
${ }^{8}$ Ognista natura smoka, powiązanego jednocześnie z żywiołem wody i powietrza, jest stałym elementem jego charakterystyki w bajce magicznej, w której zachowało się wiele pierwotnych struktur wyobrażeniowych zob. (Пропп 183-184). O pochodzeniu smoka, jego wyglądzie, sposobach działania i typowych dla niego sytuacjach fabularnych pisali m.in. Добровольская 24-40; Лызлова 214-221; Трофимов; Mianecki 477-494; Wróblewska III, 189-193.

${ }^{9}$ Utwór Wasylewskiego jest najstarszą z baśniowo-literackich wersji opowieści o Meluzynie. Por. np. Strzałka; Morcinek; Baśnie śląskie.
} 
informacji o pochodzeniu zebranych $\mathrm{w}$ antologii historii nie znajdziemy, jedynie z przedmowy wydawcy wynika, że opowieść o Meluzynie, podobnie jak pozostałe zamieszczone $\mathrm{w}$ tomie fabuły, powstała na kanwie materiałów ludowych zaczerpniętych z dzieł polskich badaczy folkloru śląskiego, Lucjana Malinowskiego i Władysława Nehringa, a także z opracowań niemieckich Schlesischer Sagenspiegel (Wasylewski 5-6). Sam Wasylewski wskazuje ponadto $\mathrm{w}$ swoim tekście na czeski kierunek zapożyczenia legendy o Meluzynie przez śląskich wykonawców: „Lud śląski, który tyle wycierpiał od niedobrych czeskich królów tej dynastii, zapoznał się też za ich pośrednictwem z niesamowitą historią" (Wasylewski 14). Natomiast zaskakujący jest fakt, że wśród źródeł inspiracji autor omawianej antologii w żaden sposób nie odnotowuje pierwszego śląskiego przekładu historii o pannie o smoczo-wężowych kształtach (z 1847 r.) autorstwa Józefa Lompy (Lompa, Historia o szlachetnej), niestrudzonego zbieracza i popularyzatora rozmaitych przejawów kultury ludowej tego regionu. Tak czy inaczej utwór Wasylewskiego wydaje się interesujący ze względu na pytanie o to, co w całej historii o wspomnianej bohaterce mogło być atrakcyjne dla nosiciela tradycji ludowej.

Jak można było przypuszczać, zainteresowały go przede wszystkim losy tajemniczej i niezwykłej istoty, co jest o tyle zrozumiałe, że mają one proweniencję ludową. Wiadomo bowiem, że legenda o Meluzynie już funkcjonowała w ustnym obiegu, kiedy obaj autorzy jej XIV-wiecznego literackiego opracowania przystępowali do sporządzenia kroniki genealogicznej rodu Lusignanów.

Przytoczona przez Wasylewskiego śląska wersja romansu składa się ze swego rodzaju introdukcji ${ }^{10}$ oraz dwóch zasadniczych części, z tym że tylko w pierwszej z nich wydarzenia przebiegają podobnie, jak w literackim pierwowzorze: spotkanie pary bohaterów w lesie, małżeństwo i towarzyszący mu zakaz nieoglądania małżonki w soboty, urodzenie synów, złamanie zakazu i zniknięcie Meluzyny. Jednocześnie obserwujemy szereg odstępstw od literackiego wzorca, prawdopodobnie wynikających z chęci uczynienia przekazu bliższym ludowemu sposobowi pojmowania świata. Inna jest przede wszystkim konkretyzacja miejsca akcji, która zostaje przeniesiona do Łysocic w powiecie głubczyckim. Tu właśnie w „ustroni leśnej” dochodzi do spotkania przyszłych małżonków, przy czym wybawcą Meluzyny nie jest dzielny rycerz, lecz jedynie ,pewien zamożny siedlak tamtejszy”. Ponadto Meluzyna rodzi mu tylko dwóch synów, choć każdy $\mathrm{z}$ nich wyróżnia się czymś

\footnotetext{
${ }^{10}$ Jest to bardzo skrótowe omówienie losów bohaterki francuskiego romansu, pomijające wiele istotnych epizodów (Wasylewski 13-14).
} 
szczególnym: pierwsze dziecko jest „ułomne jakieś i kruche”, natomiast „drugie miało tylko jedno oko na samym środku czoła” (Wasylewski 16). O ile pierwszego z synów „panny z śląskiego wiatru” trudno utożsamić z którymkolwiek z potomków bohaterki romansu, o tyle drugi przypomina piątego w kolejności - Reinharda ${ }^{11}$.

Istotnej transformacji podlega tytułowa bohaterka opowieści, której dolna część tułowia przypomina ogon ryby, nie zaś znany z literackiej redakcji historii „ogon wielki miąższy [...], jakoby jakiego smoka”, w dodatku o barwie charakterystycznej dla węża (,a barwa barzo podobna była barwie na wężu”, Historia o szlachetnej 123) czy też np. z wersji Lompy - „ogon szpetny wężowy, czyli smoka (...) w kolorze modrawym z prążkami biało śrebrzystemi i kropkowatemi”" ${ }^{2}$. Brak ponadto wyjaśnienia przyczyn antropozoomorficznej natury Meluzyny, co jednakże nie pozostaje w sprzeczności z konwencją gatunkową podania i bajki magicznej, gdzie arbitralnie się zakłada istnienie niezwykłych czarodziejskich mocy działających w świecie przedstawionym (Lugowska, Ludowa bajka 141) ${ }^{13}$. Kiedy Meluzyna opuszcza niesłownego małżonka, przeobraża się „w łagodny wietrzyk”, który w czasie burzy przybiera bardziej gwałtowne formy i daje się wówczas słyszeć „wyraźne jęki i żale wietrznicy nieszczęśliwej” (Wasylewski 16).

Wasylewski zatem - wbrew tradycji - w zasadzie pomija tak znaczący w kulturowej charakterystyce pramatki Lusignanów żywioł wody, łącząc bohaterkę swojego utworu jedynie $\mathrm{z}$ żywiołem powietrza ${ }^{14}$. Jednocześnie idzie nieco dalej w tym zakresie niż autorzy dotychczasowych opracowań losów tajemniczej kobiety, którzy raczej wprost nie utożsamiali Meluzyny $\mathrm{z}$ wiatrem, choć jej sposób poruszania się w przestworzach mógł stanowić

${ }^{11}$ „(...) porodziła zaś Meluzna syna dziwniejszego, abowiem ten między nosem a czołem prawie we śrzodku tylko jedno oko miał, we wszytkim innym udatny był" ( Historia o szlachetnej 80).

${ }^{12}$ Por. „(...) Meluzyna do połowy ciała tylko nader piękną kobietą była, odtąd zaś ciało jej w ogon szpetny wężowy, czyli smoka wychodziło, który się w kolorze modrawym z prążkami biało śrebrzystemi i kropkowatemi ślnił” (Lompa, Historia o szlachetnej 48).

${ }^{13}$ Ponadto może to być argumentem poświadczającym dawność wątku, gdyż wszelkie próby racjonalizacji cielesnej odmienności protagonistów, np. klątwą rodzicielską, uznaje się za efekt ewolucji pierwotnych wyobrażeń, pozbawionych takiej motywacji. Рor. „Видимо, это [tzn. змеиная ипостась феи Мелюзины, как результат материнского проклятия - przyp. I.Rz.] или интерпретация автора средневекового романа, или результат эволюции представлений. О подобной эволюции говорят и поздние восточнославянские версии сюжета «Жена-змея», учтенные в нашем указателе [B. IV. 1; В. IV. 2]. Ранние же версии указывают на изначальную змеиную природу героини" (Козлова).

${ }^{14}$ „Wbrew przysiędze wśliznął się w sobotni wieczór pod drzwi izby. I zajrzał przez dziurkę od klucza! I zobaczył to samo co Rajmund de Poitiers i pan luksemburski: Jego żona, ryba od pasa, czesała swe złote warkocze grzebieniem z perłowej macicy” (Historia o szlachetnej 16). 
dla odbiorcy pewną zagadkę ${ }^{15}$. Może to być rezultatem wpływu wyobrażeń funkcjonujących u czeskich sąsiadów Ślązaków ${ }^{16}$, choć równie dobrze może być wytworem rodzimej fantazji, a dokładniej - wypadkową tradycji oralno-literackiej. O ile bowiem w ludowych wierzeniach wiatr powszechnie bywa traktowany jako hipostaza różnych istot demonicznych lub zjawisko towarzyszące ich pojawieniu się (Bartmiński, Bączkowska, Prorok 307-320; Simonides I, 3, 238), to sprzężenie tego fenomenu pogodowego właśnie z imieniem Meluzyny mogło powstać pod wpływem jarmarczno-odpustowych opracowań średniowiecznego romansu, przeznaczonych dla szerokiego kręgu odbiorców. Tym samym pisarz zdaje się nawiązywać do śląskich wierzeń, w których, jak odnotował w połowie XIX wieku Józef Lompa, porywy gwałtownego wiatru traktowano jako eksplikację jęków nieszczęśliwej Meluzyny ${ }^{17}$. A jest to tym bardziej intrygujące, że popularność nomen proprium bohaterki francuskiego romansu nie szła wówczas w parze $\mathrm{z}$ aktywną recepcją jego fabuły ${ }^{18}$.

Motyw Meluzyny-wietrznicy znajduje odzwierciedlenie w drugiej części utworu Wasylewskiego, której akcja koncentruje się wokół wyzwolenia kobiety z zaklęcia. Naturalnie można to odczytać jako wyraz przeciwdziałania narratora niepożądanemu z punktu widzenia konwencji gatunkowej bajki smutnemu zakończeniu proponowanej przez niego wersji opowieści. Narracja nie zmierza jednak, jak moglibyśmy oczekiwać, w kierunku realizacji wzorca fabularnego historii o perypetiach męża poszukującego utraconej małżonki (np. T 400 „Mąż szuka utraconej żony”), lecz zawiera

\footnotetext{
${ }^{15}$ Warto zauważyć, że w spolszczonej wersji utworu autorstwa Lompy Meluzyna unosi się w powietrze dzięki trenowi: „(...) Krep długi biały owiewał ją i wyniósł ją przez okno na powietrze, a natychmiast zamieniło się ciało jej od biódr na dół w robaka nieprzyjemnego (...)”. Natomiast gdy Meluzyna trzykrotnie okrążyła zamek w powietrzu, ,zawsze jękiem ciężkim się odezwała” (Lompa, Historia o szlachetnej 62). Ponadto zwraca uwagę leksem „robak”, który w tradycji ludowej stanowi eufemistyczne określenie węża (Гypa 274). „Robak nieprzyjemny” nie jest zatem kolejnym, jakościowo innym w stosunku do poprzedniego, przeobrażeniem Meluzyny.

${ }^{16} \mathrm{~W}$ słowniku Colemana Meluzyna została zdefiniowana jako duch wiatru charakterystyczny dla obszaru Czech: „Melusina a wind-spirit in Bohemia” (Coleman 688).

17 „Lud Śląski, lubo historia o Meluzynie pomiędzy nim nie jest upowszechnioną, mówi, kiedy wiatr świszczy: Meluzyna płacze» (Lompa, Dziennik Górno-Szlazki 300). Eksploracje poczynione przez Dorotę Simonides w ubiegłym wieku poświadczają aktualność wierzeń o Meluzynie jako upostaciowaniu wiatru, choć w jej wizerunku istotną rolę zaczynają odgrywać szczegóły dotyczące źródeł jej cierpienia, np. dzieciobójstwo, rozłąka z pociechami, a nawet naruszenie zakazu związanego z nieopuszczaniem domu przez matkę do czasu wywodu, czyli chrztu potomka (Simonides 260).

${ }^{18}$ Popularność imienia Meluzyny przy niewielkim zainteresowaniu treścią utworu, którego jest ona bohaterką, charakteryzuje także folklor ukraiński z tą tylko różnicą, że zawsze bywa ona tam powiązana z żywiołem wody. Meluzynami nazywa się istoty przypominające nie tylko bohaterkę francuskiego romansu, ale i greckie syreny czy rodzime rusałki (Małek 92-93).
} 
motywy, które ze względu na konkretyzację raczej trudno przypisać do określonego wątku.

Meluzyna wyłania się z gwałtownego burzliwego wiatru, wzniecającego tumany kurzu i prosi trzech kosiarzy z Baworowa, którzy właśnie rozprawiają o jej losach, o pomoc. Kobieta uprzedza ich, że zostaną poddani działaniu żywiołów („Nadejdzie zamróz bardzo wielki i gorąc po tym bardzo wielki i burza na ostatek bardzo straszliwa”, Wasylewski 17) i jeśli sprostają próbie, wyzwolą ją z zaklęcia. Mężczyznom z trudem udaje się dotrzymać podjętego zobowiązania, zwłaszcza gdy z burzy wyłaniają się najrozmaitsze stwory, w które prawdopodobnie przeistacza się „wietrznica nieszczęśliwa”. W końcu jednak kosiarze pokonują strach i przerażenie, czym zaskarbiają sobie wdzięczność Meluzyny, objawiającą się sowitym wynagrodzeniem: „Na jasnym promieniu słonka spłynęła ku gruchlikom Meluzyna, dziękując im za wyzwolenie. I obdarowała ich sowicie" (Wasylewski 18).

Mimo pozornie szczęśliwego finału, daje się zauważyć pewna niekonsekwencja w kreowaniu przez Wasylewskiego wizji wyzwolonej z czarów bohaterki utworu. Jej obecne wcielenie nadal pozostaje owiane mgłą tajemnicy, brak bowiem wyraźnych znamion powrotu do ludzkiej postaci, co zawsze jest istotą tego rodzaju zabiegów dotyczących zdejmowania klątwy ${ }^{19}$. Dlatego trudno zgodzić się z sugestią Henryki Andrzejczak, że Meluzyna „zyskała wybawienie od pokuty” (124).

Jakkolwiek interesująca, Meluzyna, czyli panna z śląskiego wiatru nie jest ludową adaptacją francuskiego romansu, lecz jedynie śląskim, mocno zmodyfikowanym, wariantem pierwszej jego części. Poza polem obserwacji gawędziarza pozostała znaczna część utworu, traktująca o losach niezwykłych synów omawianej bohaterki. Ich potyczki z mniej lub bardziej groźnymi przeciwnikami oraz wspaniałe ożenki z osieroconymi królewnami zostały oparte na niemalże tym samym schemacie kompozycyjnym ${ }^{20}$, ale to właśnie epizody militarne i weselne są niezwykle istotne z punktu widzenia identyfikacji danej opowieści jako wariantu właśnie Historii o Meluzynie. Paradoksalnie jednak to one mogły uniemożliwić całościowe wykorzystanie

\footnotetext{
${ }^{19}$ Odczarowanie osoby płci przeciwnej zakończone małżeństwem stanowi kanwę pokaźnej liczby wątków (np. T 407 „Dziewczyna-kwiat”, T 417 „Królewna-ptak”, T 420 „Królewna-ropucha”, T 435 „Królewicz zaklęty w konia”), co wynika najprawdopodobniej z połączenia atrakcyjnych dla odbiorcy elementów magicznych z uniwersalną wymową opowieści, w której takie przymioty, jak cierpliwość, empatia i chęć niesienia bezinteresownej pomocy pozwalają bajkowym postaciom znaleźć prawdziwą miłość (Sitniewska 2, 369).

${ }^{20} \mathrm{O}$ kompozycyjno-fabularnych niedoskonałościach romansu o Meluzynie zob. np. Krzyżanowski, Romans polski 67; Małek 72.
} 
przez ludowych wykonawców Historii o Meluzynie. Jej fabuła, poszerzona o mnóstwo wątków pobocznych i epizodycznych, bardzo luźno powiązanych z centralnym wątkiem fabularnym, zapewne wydawała się zbyt skomplikowana w odbiorze i nieco monotonna. Przyczyn zatem nikłego zainteresowania romansem w polskim folklorze bajkowym należałoby upatrywać zarówno w warstwie fabularnej utworu, jak i w jego kompozycji ${ }^{21}$.

Istotną okolicznością, niesprzyjającą recepcji Historii o Meluzynie w środowisku wiejskich gawędziarzy, mogła być jej pewnego rodzaju wtórność w stosunku do pokaźnej grupy rodzimych fabuł, z których jedna rozwija motyw związku mężczyzny z kobietą reprezentującą porządek nadzmysłowy (por. np. T 400 i jego liczne odmiany fabularne, T 402 „Królewna-żaba”, T 404 „Królewna-owca”), druga zaś traktuje o starciu śmiałka $\mathrm{z}$ nadprzyrodzonym przeciwnikiem (np. T 300 „Królewna i smok”, T 301 „Bracia zdradzieccy”) 22.

\section{BIBLIOGRAFIA}

\section{ŹRÓDŁA}

Baśnie śląskie. Schlesische Märchen. Oprac. Małgorzata Zalewska-Zemła, Wokół nas, 1997.

Historia o szlachetnej a pięknej Meluzynie. Oprac. Roman Krzywy, Wydawnictwo Naukowe Sub Lupa, 2015.

Krzyżanowski, Julian. Polska bajka ludowa w uktadzie systematycznym, t. 1. Zakład Narodowy im. Ossolińskich, 1962.

Lompa, Józef. Historia o szlachetnej i pięknej Meluzynie, która była dziworodem morskim i córka króla Helmona. Czcionkami i nakładem F. Kuhnerta, 1847, ss. 142-178.

Morcinek, Gustaw. Legendy i baśnie. Wyboru dokonał i posłowiem opatrzył Witold Nawrocki, Śląsk, 1984.

Strzałka, Brunon. Godki i bojki śląskie. Instytut Śląski, Opolskie Towarzystwo Kulturalno-Oświatowe, 1976.

Uther, Hans-Jörg. The types of international folktales. A classification and bibliography, t. 1. Suomalainen Tiedeakatemia, Academia Scientiarum Fennica, 2011.

Wasylewski, Stanisław. Legendy i baśnie śląskie. Ognisko, 1947, ss. 13-18.

\footnotetext{
${ }^{21}$ Niniejszy tekst jest zmienioną i rozbudowaną wersją hasła przygotowanego na potrzeby słownika polskiej bajki ludowej (Rzepnikowska 2, 363-366).

${ }^{22} \mathrm{Z}$ podobną sytuacją mamy do czynienia w rosyjskim folklorze bajkowym, w którym także nie odnotowano śladów zainteresowania Historia o Meluzynie (Małek 91-92). Natomiast szeroko reprezentowane są opowieści o innych zooantropomorficznych istotach, z których najpierwotniejsza jest pół kobieta, pół wąż. „Восточнославянский материал дает следующие ипостаси мифической жены: женщина-змея, женщина-птица (лебедушка), летавица, ветреница, водяная девушка, женщина-ангел, гуменникова дочка, вихрева дочка. В начале этого ряда стоит образ жены-змеи" (Козлова).
} 


\section{OPRACOWANIA}

Andrzejczak, Henryka. „Motyw Meluzyny-wietrznicy w śląskich podaniach”. Śląskie Miscellanea, t. 12, 1999, ss. 117-126.

Bartmiński, Jerzy, Grażyna Bączkowska, Katarzyna Prorok. „Wiatr”. Słownik stereotypów i symboli ludowych. I. Kosmos. 3. Meteorologia, red. Jerzy Bartmiński i Stanisława Niebrzegowska, Wydawnictwo UMCS, 2012, ss. 307-320.

Benedyktowicz, Zbigniew. Portrety obcego. Od stereotypu do symbolu. Wydawnictwo UJ, 2000.

Coleman, James. A. The Dictionary of Mythology. An A-Z of Themes - Legends and Heroes. Arcturus Publishing Limited, 2007.

Eliade, Mircea. Traktat o historii religii. Przeł. Jan Wierusz-Kowalski, Książka i Wiedza, 1966.

Le Goff, Jacques, and Emmanuel Le Roy Ladurie. „Mélusine maternelle et défricheuse”. Annales. Économies. Sociétés. Civilisations, t. 26, nr 3-4, 1971, ss. 587-622.

Heisig, Karl. „Über den Ursprung der Melusinensage”. Fabula, t. 3, nr 1, 1960, ss. 170-181.

Kohler, Josef. Der Ursprung der Melusinensage. Eine ethnologische Untersuchung. Verlag von Eduard Pfeiffer, 1895. archive.org/details/KohlerDerUrsprungDerMelusinensage/page/n19. Dostęp 17.07.2019.

Krzywy, Roman. „Wstęp”. Historia o szlachetnej a pięknej Meluzynie. Opracował Roman Krzywy, Wydawnictwo Naukowe Sub Lupa, 2015, ss. 5-33.

Krzyżanowski, Julian. Romans polski wieku XVI. Państwowy Instytut Wydawniczy, 1962.

Lecouteux, Claude. „La Structure des légendes mélusiniennes”. Annales. Économies. Sociétés. Civilisations, t. 33, nr 2, 1978, ss. 294-306.

Lecouteux, Claude. „Zur Entstehung der Melusinensage”. Zeitschrift für deutsche Philologie, t. 98,1979 , ss. 73-84 .

Lompa, Józef. Dziennik Górno-Szlązi, nr 75, 1849, ss. 300.

Ługowska, Jolanta. „Meluzyna”. Stownik literatury popularnej, red. Tadeusz Żabski, Towarzystwo Przyjaciół Polonistyki Wrocławskiej, 1997, ss. 258-259.

Ługowska, Jolanta. Ludowa bajka magiczna jako tworzywo literatury. Zakład Narodowy im. Ossolińskich, 1981.

Majer-Baranowska, Urszula. „Woda”. Stownik symboli i stereotypów ludowych. I: Kosmos. Cz. 2: Ziemia, woda, podziemie, red. Jerzy Bartmiński i Stanisława Niebrzegowska, Wydawnictwo UMCS, 1999, ss. 153-187.

Małek, Eliza. Historia o Meluzynie. Z dziejów romansu rycerskiego na Rusi. Wyższa Szkoła Pedagogiczna w Bydgoszczy, 1978.

Melusine's Footprint: Tracing the Legacy of a Medieval Myth, red. Misty Urban, Deva F. Kemmis and Melissa Ridley Elmes, Brill, 2017.

Mianecki, Adrian. „Przekleństwo królów, plaga królestw - smok w wybranych opowieściach polskiego folkloru tradycyjnego". Powodzie, plagi, życie i inne katastrofy, red. Katarzyna Konarska i Piotr Kowalski, Uniwersytet Wrocławski, 2012, ss. 477-494.

Mieletinski, Eleazar. Poetyka mitu. Przeł. Józef Dancygier, Państwowy Instytut Wydawniczy, 1981.

Moszyński, Kazimierz. Kultura ludowa Stowian, t. 2: Kultura duchowa. Polska Akademia Umiejętności, 1967-1968. 
Ruh, Kurt. Die ,Melusine des Thüring von Ringoltingen. Bayerische Akademie der Wissenschaften, 1985, publikationen.badw.de/de/000415317.pdf. Dostęp 17.07.2019.

Rzepnikowska, Iwona. „Meluzyna”. Stownik polskiej bajki ludowej. 2, red. Violetta Wróblewska, Wydawnictwo UMK, 2018, ss. 363-366, www.bajka.umk.pl. Dostęp 27.09.2019.

Simonides, Dorota. „Wierzenia i zachowania przesądne”. Folklor Górnego Śląska, red. Dorota Simonides, Wydawnictwo Śląsk, 1989, ss. 225-301.

Sitniewska, Roksana. „Metamorfoza”. Słownik polskiej bajki ludowej, red. Violetta Wróblewska, Wydawnictwo UMK, 2018, ss. 366-373. www.bajka.umk.pl. Dostęp 27.09.2019.

Walter, Philippe. La Fée Mélusine: le serpent et l'oiseau. Imago, 2008.

Wróblewska, Violetta. Ludowa bajka nowelistyczna (źródta - watki - konwencje). Wydawnictwo UMK, 2007.

Wróblewska, Violetta. „Smok”. Słownik polskiej bajki ludowej, red. Violetta Wróblewska, Wydawnictwo UMK, 2018, www.bajka.umk.pl. Dostęp 27.09.2019.

Zhao, Zifeng. Metamorphoses of snake women, Melusine and Madam White. The University of British Columbia (Vancouver). 2015, open.library.ubc.ca/cIRcle/collections/ ubctheses/24/ items/1.0166536. Dostęp 27.09.2019.

Виноградова, Людмила Н. „Вода”. Славянские древности. Этнолингвистический словарь. I, ред. Никита Толстой, Институт славяноведения РАН, 1995, сc. 386-390 [Vinogradova, Lyudmila N. „Voda”. Slavyanskiye drevnosti. Etnolingvisticheskiy slovar'. I, red. Nikita Tolstoy, Institut slavyanovedeniya RAN, 1995, ss. 386-390].

Гура, Александр. Символика животных в славянской народной традиции. Индрик, 1997 [Gura, Aleksandr. Simvolika zhivotnykh v slavyanskoy narodnoy traditsii. Indrik, 1997].

Добровольская, Варвара. „Змей в русской волшебной сказке: к вопросу о природе и генезисе персонажа". Традиционная культура, nr 2 (26), 2007, cc. 24-40 [Dobrovol'skaya, Varvara. „Zmey v russkoy volshebnoy skazke: $\mathrm{k}$ voprosu o prirode i genezise personazha". Traditsionnaya kul'tura, nr 2 (26), 2007, ss. 24-40].

Козлова, Наталья К. „Восточнославянские мифологические рассказы о змеях”. Cистематика. Исследование. Тексты. Наука, 2006 [Kozlova, Natal'ya K. „Vostochnoslavyanskiye mifologicheskiye rasskazy o zmeyakh". Sistematika. Issledovaniye. Teksty. Nauka, 2006]. www.ruthenia.ru/folklore/kozlova7.htm. Dostęp 23.08.2019.

Лызлова, Анастасия. „Змей - похититель женщин в русских волшебных сказках: об истоках и трансформациях образа”. „Калевала” в контексте региональной и мировой культуры, ред. Ирма И. Муллонен. Карельский научный центр РАН, 2010, сс. 214221 [Lyzlova, Anastasiya. „Zmey - pokhititel’ zhenshchin v russkikh volshebnykh skazkakh: ob istokakh i transformatsiyakh obraza”. ,Kalevala” $v$ kontekste regional'noy i mirovoy kul'tury, red. Irma I. Mullonen, Karel'skiy nauchnyy tsentr RAN, 2010, ss. 214-221].

Пропп, Владимир Я. Исторические корни волшебной сказки. Лабиринт, 2000 [Propp, Vladimir Ya. Istoricheskiye korni volshebnoy skazki. Labirint, 2000].

Трофимов, Георгий А. Мотив змееборчества в русской сказке и былине: к вопросу о национальной специфике. Йошкар-Ола 2018 [Trofimov, Georgiy A. Motiv zmeyeborchestva v russkoy skazke $i$ byline: $k$ voprosu o natsional'noy spetsifike. Yoshkar-Ola 2018], mpgu.su/wp-content/uploads/2018/03/Trofimov_Dissertatsiya.pdf. Dostęp 3.08.2019. 


\section{PIĘKNA (NIE)OBECNA, \\ CZYLI MELUZYNA W POLSKIM FOLKLORZE BAJKOWYM}

\section{Streszczenie}

Celem artykułu jest próba odpowiedzi na pytanie o sposób funkcjonowania w polskim folklorze bajkowym i, szerzej, w rodzimej kulturze ludowej średniowiecznej powieści rycerskiej Historia o Meluzynie. Można mówić jedynie o pośredniej znajomości tej fabuły, o czym świadczy jej przeróbka literacka pt. Meluzyna, czyli panna z śląskiego wiatru (1947), autorstwa Stanisława Wasylewskiego. Pisarz powołuje się na ustalenia polskich badaczy folkloru, a także wskazuje na przekazywane drogą ustną opowiadania o tajemniczej dziewczynie, które były źródłem jego inspiracji twórczej. Utwór Wasylewskiego odzwierciedla jedynie pierwszą część francuskiego romansu, co prawdopodobnie wskazuje na rzeczywistą znajomość owej historii przez nosicieli tradycji ludowej. Istotne jest ponadto, że bohaterka utworu Wasylewskiego zostaje powiązana jedynie z żywiołem wiatru. Dlatego są podstawy, by sądzić, że w ten sposób pisarz odwołuje się do śląskich wierzeń, według których porywy gwałtownego wiatru były eksplikacją jęków nieszczęśliwej Meluzyny. Jak można przypuszczać, obszerna część Historii o Meluzynie, opowiadająca o przygodach synów niezwykłej matki, pozostała poza polem twórczej obserwacji pisarza ze względu na zbytnią złożoność fabularno-kompozycyjną.

Słowa kluczowe: Historia o Meluzynie; kobieta-wąż; polska baśń ludowa; śląskie baśnie i legendy; Stanisław Wasylewski.

\section{THE BEAUTIFUL (UN)PRESENT: THE FIGURE OF MELUSINE IN POLISH FOLK TALES}

\section{S u m m ary}

This article seeks to answer questions concerning the presence and function of Historia o Meluzynie (the Polish translation of the French Le Roman de Mélusine), a medieval romance, in Polish folk tales and, in more general terms, Polish folk culture. One can speak only of indirect evidence of knowledge of the story, as exemplified by Meluzyna, czyli panna z ślaskiego wiatru (1947) [Melusine, or a Maiden of the Silesian Wind], a literary adaptation by Stanisław Wasylewski. The author of this version refers to the studies contributed by native folklore researchers and to oral tales about this mysterious maiden, which, for him, were sources of creative inspiration. Wasylewski's work relates to only the first part of the French romance, which perhaps indicates the actual state of knowledge of the story displayed by folk storytellers, especially as the heroine of Wasylewski's text is connected with the element of the wind. This can be interpreted as the author's reference to the Silesian belief in which gusts of violent wind were treated as the moans let out by the figure of the unhappy Meluzyna. It would appear that the extensive fragment of Le Roman de Mélusine concerning the fate of her sons remained beyond the scope of folklore- and literary-specific observation due to there being too much story- and compositionlinked complexity.

Key words: Historia o Meluzynie (Le Roman de Mélusine); snake woman; Polish folk tale; Silesian legends and tales; Stanisław Wasylewski. 